\title{
Forest research at the Turkey Lakes Watershed
}

\author{
by I.K. Morrison ${ }^{1}$, D.A. Cameron ${ }^{1}$, N.W. Foster ${ }^{1}$, and A. Groot ${ }^{1}$
}

The $10.5 \mathrm{~km}^{2}$ Turkey Lakes Watershed, located on the Precambrian Shield approximately $60 \mathrm{~km}$ north of Sault Ste. Marie, Ontario, is occupied by a typical Great Lakes-St. Lawrence sugar mapleyellow birch forest. Since late 1979, the watershed has been the site of an interdisciplinary study on impacts of long-range transported air pollutants on the biology of forests, lakes and streams, and the recovery of terrestrial and aquatic ecosystems in response to reduced pollutant deposition. A knowledge base on forest growth, soils and hydrology, with detailed climate and precipitation chemistry records dating back nearly twenty years has been developed. This history, plus an available infrastructure, makes the watershed an ideal site to study processes across the terrestrial-aquatic interface. A harvesting impacts project, for example, was started in 1997. This project is built around a field experiment comparing clear-felling, shelterwood, and single-tree selection versus uncut control, for appropriateness of application and for impacts on long-term soil productivity, stand function, diversity of plant and animal life, and hydrological and other on- and offsite impacts. The watershed is also a site for the ECOLEAP Project, which is attempting to improve overall understanding of mechanisms controlling forest productivity, and a site to test terrain and climate models to model temperature, moisture, energy and nutrients and the relationship of these to species distribution, abundance and productivity at different scales up to the watershed level.

Key words: acid precipitation, air pollution, biogeochemistry, research site, watershed
Les $10,5 \mathrm{~km}^{2}$ du bassin des Turkey Lakes, situé sur le Bouclier précambrien à environ $60 \mathrm{~km}$ au nord de Sault-Ste-Marie, en Ontario, sont couverts par une érablière à bouleau jaune typique des Grands-Lacs-St-Laurent. Depuis la fin de 1979, le bassin a été au coeur d'une étude interdisciplinaire des impacts des polluants aériens transportés sur de grandes distances sur la biologie des forêts, des lacs et des cours d'eau, et sur la récupération des écosystèmes terrestres et aquatiques suite à la réduction des dépôts de polluants. Une connaissance fondamentale de la croissance forestière, des sols et de l'hydrologie, ainsi que des données détaillées sur le climat et la composition chimique des précipitations sur un horizon de près de 20 ans, a été élaborée. Cet historique, en plus de l'infrastructure disponible, font de ce bassin un site idéal d'étude des processus affectant l'interface terrestre-aquatique. Un projet d'étude des impacts de la récolte, par exemple, a débuté en 1997. Ce projet est élaboré autour d'une expérience sur le terrain où l'on compare la coupe à blanc, la coupe progressive, et la coupe sélective par rapport à un témoin, afin de déterminer le choix du mode et les impacts à long terme sur la productivité du sol, la fonction du peuplement, la diversité des plantes et des animaux, et les impacts hydrologiques et autres sur et à l'extérieur du site. Le bassin est également un site du projet ECOLEAP qui cherche à améliorer la compréhension globale des mécanismes qui contrôlent la productivité forestière, et un site pour tester des modèles de terrain et de climat afin de représenter la température, l'humidité, l'énergie et les éléments nutritifs ainsi que les relations de ces intrants par rapport à la distribution, l'abondance et la productivité des espèces à différents niveaux allant jusqu'à l'ensemble du bassin.

Mots-clés: pluie acide, pollution atmosphérique, biogéochimie, site de recherche, bassin

\section{Introduction}

The Turkey Lakes Watershed is located (lat. $47^{\circ} 03^{\prime} \mathrm{N}$; long. $87^{\circ} 24^{\prime} \mathrm{W}$ ) in Algoma District, northern Ontario, approximately $60 \mathrm{~km}$ north of Sault Ste. Marie and $13 \mathrm{~km}$ inland from Batchewana Bay on Lake Superior. The watershed is in the Algoma Section (L.10) of the Great Lakes-St. Lawrence Forest Region (Rowe 1972) and is occupied by a remnant of unevenaged, but generally mature to over-mature, sugar maple (Acer saccharum Marsh.) - yellow birch (Betula alleghaniensis Britton) forest, typical of upland sites in the region (Fig. 1). The overall watershed is approximately $10.5 \mathrm{~km}^{2}$ in area, is underlain by Precambrian greenstone and granite, and is drained through a cascading system of lakes, beginning with a small headwater lake, then through two downstream lakes into Turkey Lake, and eventually into the Batchewana River and Lake Superior. Topography is rugged, with approximately $400 \mathrm{~m}$ of relief between the highest point on the watershed, the top of Batchewana Mountain at $640 \mathrm{~m}$, and the

\footnotetext{
${ }^{1}$ Canadian Forest Service, Great Lakes Forestry Centre, P.O. Box 490, 1219 Queen Street East, Sault Ste. Marie, Ontario P6A 5M7. E-mail: Imorriso@nrcan.gc.ca
}

watershed outflow at $240 \mathrm{~m}$. For the most part, soils consist of approximately $0.5 \mathrm{~m}$ of silty-loam ablation till over compacted basal till. Soils are typically shallow on crests and upper slopes and increase in depth down slope. Both tills are of mixed basaltic-granitic origin.

Research on the Turkey Lakes Watershed began in 1979, when the watershed was chosen as the site of a multi-disciplinary study of impacts of long range transported air pollutants. The main participants in this study were Canadian Forest Service (CFS), Department of Fisheries and Oceans (DFO), Inland Waters Directorate (IWD) and Atmospheric Environment Service (AES) of Environment Canada, and Sault Ste. Marie District of Ontario Ministry of Natural Resources (MNR). The overall objective of this first Turkey Lakes Watershed Study was "to define the impact of atmospheric deposition of acidifying substances on undeveloped aquatic and terrestrial terrain" (Jeffries et al. 1988a,b). During the mid1980 s, several forest biomonitoring plots were installed on the watershed and, recently, a new project, the objective of which is to compare alternative silvicultural systems, was also initiated. The watershed was also recently selected as a location for an installation of another project, aimed at understanding mechanisms underlying forest productivity. The following is 
a brief review of some of the major forestry studies at Turkey Lakes Watershed from 1979 to the present.

\section{Long-Range Transport of Air Pollutants (LRTAP) Project}

During the 1970 s, the pollutant of foremost concern to much of the industrialized world, including most of eastern North America, was "acid precipitation," that is, natural precipitation (rain, snow, fog, etc.) augmented with man-made strong acids (chiefly sulphuric and nitric acids). The chief precursors of these acids were sulphur dioxide $\left(\mathrm{SO}_{2}\right)$, primarily from coal combustion and, to a lesser extent, from petroleum refining and combustion, and from mineral smelting, and oxides of nitrogen $(\mathrm{NOx})$, primarily from the transportation sector.

During late 1978, researchers from CFS, IWD, and DFO undertook to establish a research site in central northern Ontario to study impacts of acid deposition on receptor ecosystems that would complement already-established sites in northwestern Ontario (Experimental Lakes Area) and near Dorset in central Ontario. The emergence of acid deposition as public issue in early 1979 accelerated the process. Between early spring and late summer of the same year, a search committee was formed, selection criteria were agreed upon, 100 candidate systems were considered, 30 were ground-truthed, two were short-listed, and one (Turkey Lakes) was selected. Following this, reserves and withdrawals-from-staking were negotiated with the MNR, approximately $15 \mathrm{~km}$ of road were rebuilt, a trailer was installed, weirs were built and, by late fall 1979, the first collections of data were made.

During the late 1970 s and early 1980 s, impacts on aquatic resources, both water and aquatic biota, commanded the most attention. Forestry research at Turkey Lakes was directed primarily at site characterization (Jeffries et al. 1988a) and at quantifying biogeochemical processes in sugar maple-yellow birch ecosystems in general. The latter included processes such as foliar and soil leaching and effects such leaching might have on forest productivity, and the role of forests in modifying inputs to streams and larger water bodies. Forest research activities were organized around small calibrated catchments and "intensive study sites" where forest growth and biogeochemical processes (canopy interception/leaching, throughfall, forest floor and soil leaching, litterfall and litter decomposition) were examined in detail (Fig. 2). The objective was to develop, calibrate and test process models to help elucidate impacts of anthropogenic acids on forest ecosystems, and to trace the pathways of water and ions from the atmosphere through the forest and soil to the outlets of forest streams. Much research was focussed on the leaching of base cations such as calcium and magnesium from the soil, and the possibility that this could lead to soil impoverishment and productivity decline. Relatively large effluxes of sulphate, nitrate and cations were observed (Foster and Nicolson 1983, Foster 1985 ) as well as a large natural production of nitrate-ions from within the soil. It was calculated that $c a$. $31 \%$ of the total anionic charge, hence cation leaching, resulted from atmospheric sulphate and nitrate (Foster et al. 1986, 1989). It was generally concluded, however, that, only under conditions of greatly accelerated acid loading and on very base-deficient sites might pollutant-mobilized base loss be a problem. In general, active recycling of elements together with weathering of primary minerals could be expected to assist in preserving the base status of the site (Morrison et al. 1992). The fieldwork phase of Turkey Lake's original forestry LRTAP Project, with its biogeochemical focus, was conducted during $1980-85$, and was continued a further three years under the Integrated Forest Study (IFS), a description of which follows.

\section{Integrated Forest Study}

The IFS, an ecosystem-level study of processes of nutrient transfer linking the atmosphere, living plants and animals, soil and soil water (Electric Power Research Institute 1986), was also concerned with potential impacts of acid deposition. This study was conducted simultaneously at locations across North America and at one site in Norway during 1986-89. Only minor changes in protocol were required to incorporate the Turkey Lakes forestry work into the IFS. In the IFS, atmospheric acid inputs and their impacts on nutrient cycling were quantified across a range of vegetation and soil types. Sites were rated for sulphate retention, nitrate biological retention / production, and loss of base cations and aluminium from the soil. Striking differences were found among sites, which could be explained simply by atmospheric deposition differences. Nitrate losses from Turkey Lakes soils were, in fact, amongst the highest, exceeding $750 \mathrm{~mol} / \mathrm{ha} / \mathrm{yr}$, and were attributable to the high mineralization / nitrification potential of the soil. Data from IFS sites were ultimately used to calibrate and validate the nutrient-cycling model, NuCM (Johnson and Lindberg 1992).

\section{Biomonitoring Plots}

During the mid-1980s, concern arose in Europe regarding a new forest decline and the possibility that this was linked to acid deposition. In North America, declines of red spruce (Picea rubens Sarg.), principally in New England, and sugar maple, mainly in Quebec and southern Ontario were reported and captured the attention of forest scientists. In Canada, this led to the development of the Acid Rain National Early Warning System (ARNEWS), a coast-to-coast network of biomonitoring plots. The objectives of the ARNEWS are to detect damage to forest trees and soils caused by air pollutants (or, at least, to identify damage not attributable to natural causes and management practices), and to monitor vegetation and soils to detect long-term changes attributable to air pollutants in representative forest ecosystems (Addison 1989, D'Eon et al. 1994). A second initiative, the North American Maple Project (NAMP), was a joint USA-Canada biomonitoring network focussed mainly on sugar bushes (Lachance et al. 1995). ARNEWS and NAMP plots were both established at Turkey Lakes Watershed, though the plots served mainly to characterize background conditions, because the watershed was generally beyond the affected area. Thus, Turkey Lakes became home to both biogeochemical monitoring and biomonitoring activities.

\section{Turkey Lakes Harvesting Impacts Project}

During the early 1990s, a resurgence of interest in impacts of forestry practices in response to Criteria and Indicators (Canadian Council of Forest Ministers 1995, Canadian Forest Service 1995) and Certification initiatives led to the development of new research directions at the Turkey Lakes Watershed. Chief amongst these was the Turkey Lakes Harvesting Impacts Project. Computer simulations of nutrient removals in harvested 


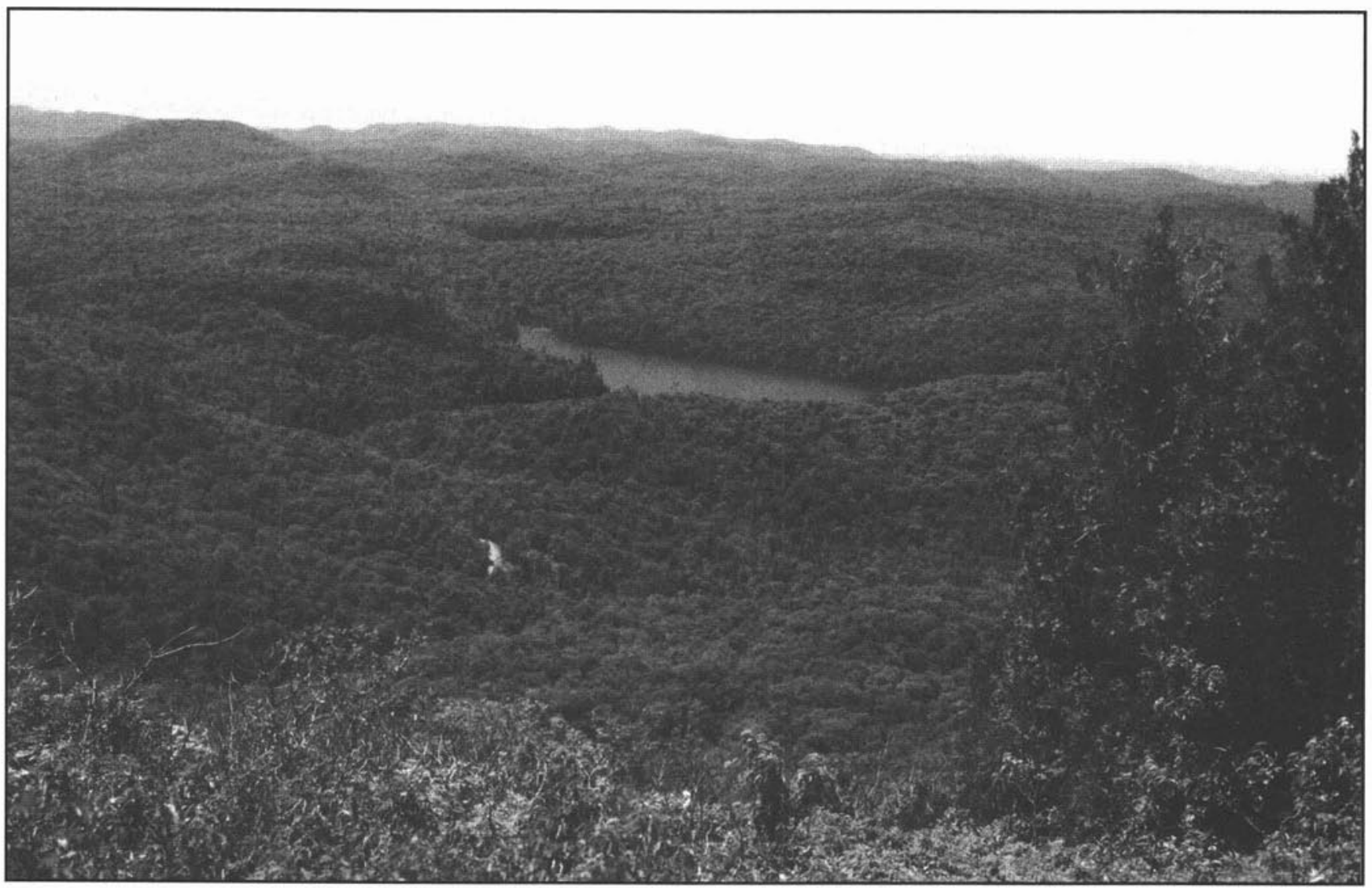

Fig. 1. The $10 \mathrm{~km}^{2}$ Turkey Lakes Watershed is a rugged Precambrian Shield landscape of hardwood forest, soils, streams and lakes.

products (Bhatti and Foster 1996) had rekindled a longstanding interest in harvesting and its relationship to sustainable forestry. Impacts of forestry practices on biodiversity over the long-term were also of interest. This new project had the support of long-time partners, IWD, AES and DFO as well as new partners, including the Ontario Forest Research Institute (OFRI) and Southcentral Science, both of the MNR, and forest industry. The latter included Clergue Forest Management Inc. and Agawa Forest Products Ltd. A much-needed market for low-end hardwood removals was provided by E.B. Eddy, Agawa's parent company, through their Espanola, Ontario mill.

The core experiment of the Turkey Lakes Harvesting Impacts Project is a randomized block field trial, comparing alternative silvicultural systems, namely, single-tree selection, shelterwood, clear-felling, and uncut control, both for applicability to forests in the area in general and with regard to potential on- and off-site impacts. Objectives included quantifying impacts of these alternative harvesting systems and associated practices on: (1) soil and its productivity over the long-term; (2) stand function, including the recovery of net primary production (NPP) and recovery of carbon and nutrient cycling; (3) successional pathways and processes and on biodiversity; (4) water yield and quality, and fauna in forest streams; (5) developing environmentally-sustainable forest management systems; and (6) using remote sensing as a way of extending findings beyond the study area.

The Project got underway in a practical sense with a harvest in 1997. In selection and shelterwood compartments, trees were marked by company markers. The harvest was by fellerbuncher with on-site delimbing, cable skidder forwarding to roadside. In selection compartments, the marking prescription called for a residual basal area of 18 square metres per hectare distributed across pole, small-, medium- and large-sawlog size classes in a 5:9:2:2 ratio. The shelterwood prescription was based on a two-coup uniform shelterwood model. In the seeding cut, marking deviated from the prescription, however, to spare significant patches of established yellow birch poles. This latter was in accordance with a long-term silvicultural goal to increase the yellow birch component of the stand, which is currently overwhelmingly sugar maple. The second felling coup is planned for 2007, provided that a good regeneration has been achieved. Clear felling is not currently recommended by managers for tolerant hardwood management in the area, but was included in order to study effects associated with a high biomass-removal treatment.

\section{ECOLEAP Project}

Finally, the Watershed will be the location of an installation of the Extended Concertation for Linking Ecophysiology and forest Productivity (ECOLEAP) Project, an initiative of CFS's Ecosystem Processes, Landscape Management and Climate Change Networks (Canadian Forest Service 1998). The main impetus for this project came from Laurentian Forestry Centre, but with participation from Atlantic and Great Lakes Centres as well. Developing an understanding of factors controlling forest productivity, and improving our ability to predict productivity both regionally and at finer scales 


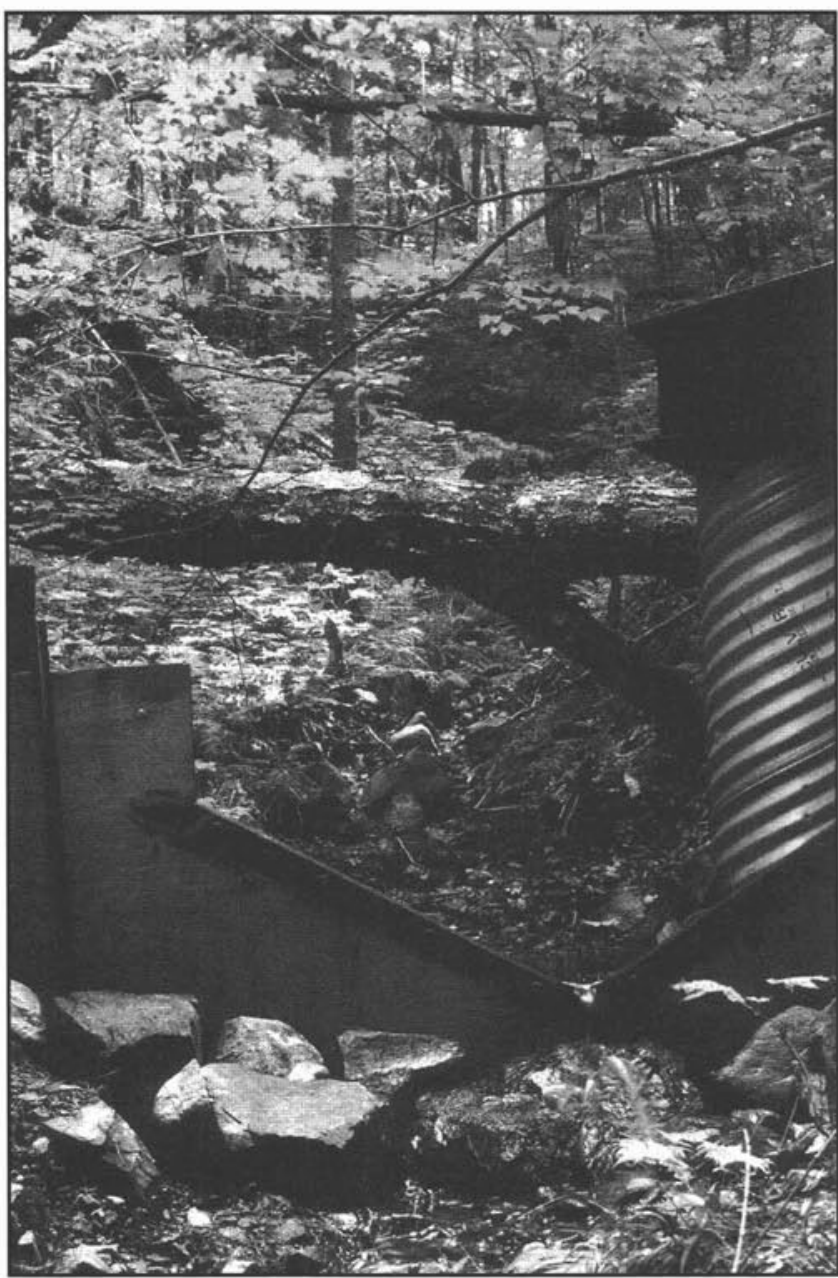

Fig. 2. Water/materials budgets were monitored in small, forested basins distributed over the watershed.

are the two principal objectives of the ECOLEAP project. The proposed areas of focus are as follows: (1) measuring NPP in major eastern forest ecosystems across climate or fertility gradients, (2) determining relationships between specific physical and biological factors, and species composition and ecosystem NPP, (3) developing tools to predict and monitor sustainable potential NPP under both natural and managed scenarios. As with aspects of the Harvesting Impacts Project, the ECOLEAP Project at Turkey Lakes Watershed will focus on sugar maple NPP, though with a more in-depth emphasis on physiology and carbon cycling. Areas of overlap between the two projects will be exploited. As well, the watershed serves to test the ability of terrain and climate models to model temperature, moisture, energy and nutrients, and the relationship of these variables to species distribution, abundance and productivity at different scales of resolution up to the watershed level.

\section{Organization and Funding}

Research at Turkey Lakes Watershed is coordinated by a Steering Committee, made up of two representatives (one scientist and one accountable manager), from each of CFS, IWD, DFO, and MNR Sault Ste Marie District, which meets formally one or two times per year. Steering Committee dis- cussions tend to centre on budget and field operations. The field site and a water analysis laboratory (housed at the Great Lakes Forestry Centre, Sault Ste. Marie) have been operated by the main participants by a joint pooling of resources since the original project inception. The Committee vets new proposals, generally oversees infrastructure items, maintains publication lists and has organized workshops. Most importantly, however, the Steering Committee serves as a point of contact between researchers. Funding is the responsibility of individuals and individual agencies. Long term tenure and funding are always of concern. However, it was decided that the project's worth should first be proved to both research and forest managers, and only then worry about tenure and funding. The project is now in its twentieth year, despite the fact that neither tenure nor funding horizons ever exceeded five years. Close to two hundred scientific and technical publications have been produced.

\section{Some Lessons Learned}

First, much environmental science is issue-driven. Early work at Turkey Lakes Watershed, both in aquatic and terrestrial science areas, was in response to the acid deposition issue. Expansion of this during the 1980s was in response to forest decline. Current initiatives address sustainable forestry and climate change issues.

Second, broadly based, in-depth support is essential. During the 1970s, there was substantial interest in the scientific community regarding long-range transported air pollutants. It was not, however, until "acid rain" became a public issue in early 1979 that it captured the attention of politicians and, in turn, bureaucrats and managers. Issues are usually bandied about in scientific circles for some time before becoming public. This time should be spent constructively in planning.

Next, an overall vision is essential. "Defining the impact of atmospheric deposition of acidifying substances" may or may not have been imagination-capturing, but it did assist in scoping the project and providing focus. Related is a framework around which to organize individual parts. In the early Turkey Lakes Watershed Study, we proposed to develop and/or calibrate computer models, based on observations and experiments at the watershed. The current Turkey Lakes Harvesting Impacts Project is organized around a large field experiment. Forestry is multi-disciplinary; forestry problems are frequently multifaceted. Forest managers draw on a wide range of disciplines in their day-to-day work. Forest research should be structured in the same way. Since no single individual can master all of the fields needed to make in-depth progress in science on all fronts, it is essential that the work be organised in such a way that linkages can be made between the various pieces. Working together on common projects and on common sites is the most straightforward way to achieve this.

Finally, site selection is critical. If a location meets a broad range of well considered criteria and is of sufficient size for future expansion, it is more likely to endure than a site selected for a narrower purpose. A good site should be representative of a significant forest association, large enough for current purposes and for future expansion, and networked with other sites to facilitate comparisons and contrasts. The Turkey Lakes Watershed Study is a comprehensive, interdisciplinary, ecosystem research project. Selection criteria included resistant geology, a cascade of lakes, breeding fish stocks (prefer- 
ably trout), uniform, relatively-undisturbed forest typical of the area, tenure available (or, at least, not allocated for harvest within foreseeable future), within driving distance of a central laboratory, and having good on-site access. In northern Ontario, there is no shortage of rocks, lakes and trees. To get the right mix, however, and do this within the constraints of land tenure, distance and on-site access requirements, it was necessary to start with one hundred systems, to ground-truth thirty, to short list two, to get just one.

\section{References}

Addison, P.A. 1989. Monitoring the health of forests: a Canadian approach. Environ. Monitor. Assess. 12: 39-48.

Bhatti, J.S. and N.W. Foster. 1996. Computer model predicts diminished productivity of tolerant hardwood forest following fulltree harvesting. Can. Forest Serv., Sault Ste. Marie, ON, Frontl. Tech. Note 92.4 p.

Canadian Council of Forest Ministers. 1995. Sustainable Forest Management. A Canadian Approach to Criteria and Indicators. Can. Forest Serv., Ottawa, ON. 22 p.

Canadian Forest Service. 1995. Criteria and Indicators for the Conservation and Sustainable management of temperate and boreal forests. The Montreal Process. Can. Forest Serv., Hull, QC. 28 pp. Canadian Forest Service. 1998. ECOLEAP. Linking ecophysiology and forest productivity. Can. Forest Serv., Ste-Foy, QC. brochure. D'Eon, S.P., L.P. Magasi, D. Lachance and P. Desrochers. 1994. ARNEWS. Canada's national forest health monitoring plot network. Manual on plot establishment and monitoring (revised). Can. Forest Serv., Chalk River, ON. Inf. Rep. PI-X-117.

Electric Power Research Institute. 1986. Integrated Forest Study. Tech. Brief, Electric Power Res. Inst., Palo Alto, CA. 4 p.
Foster, N.W. 1985. Acid precipitation and soil solution chemistry within a maple-birch forest in Canada. Forest Ecol. Manage. 12: 215-231. Foster, N.W. and J.A. Nicolson. 1983. Acid precipitation and vegetation interaction in the Turkey Lakes Forest Watershed. Can. Forest. Serv. Res. Notes 3: 6-7

Foster, N.W., P.W. Hazlett, J.A. Nicolson and I.K. Morrison. 1989. Ion leaching from a sugar maple forest in response to acidic deposition and nitrification. Water Air Soil Pollut. 48: 251-261.

Foster, N.W., I.K. Morrison and J.A. Nicolson. 1986. Acidic deposition and ion leaching from a podzolic soil under hardwood cover. Water Air Soil Pollut. 31: 979-890.

Jeffries, D.S., J.R.M. Kelso and I.K. Morrison. 1988a. Physical, chemical, and biological characteristics of the Turkey Lakes Watershed, central Ontario, Canada. Can. J. Fish Aquat. Sci. 45 (Suppl. No. 1): 3-13.

Jeffries, D.S., I.K. Morrison and J.R.M. Kelso. 1988b. The Turkey Lakes watershed study. In Can. Hydrol. Symp (CHS-88), Nat. Res. Counc. Can., May 9-11, 1988. pp.117-126. Banff, AB.

Johnson, D.W. and S.E. Lindberg (eds.). 1992. Atmospheric Deposition and Forest Nutrient Cycling. Springer-Verlag, New York, NY, Ecol. Studies 91. 707 p.

Lachance, D., A. Hopkin, B. Pendril and J.P. Hall. 1995. Health of sugar maple in Canada. Results of the North American Maple Project 1988-1993. Can. Forest Serv., Ottawa, ON, Inf. Rep. ST-X-10. 27 p.

Morrison, I.K., N.W. Foster and J.A. Nicolson. 1992. Influence of acid deposition on element cycling in mature sugar maple forest. Water Air Soil Pollut. 61: 243-252.

Rowe, J.S. 1972. Forest Regions of Canada. Can. Forest. Serv., Ottawa ON. Publ. 1300,172 p. 